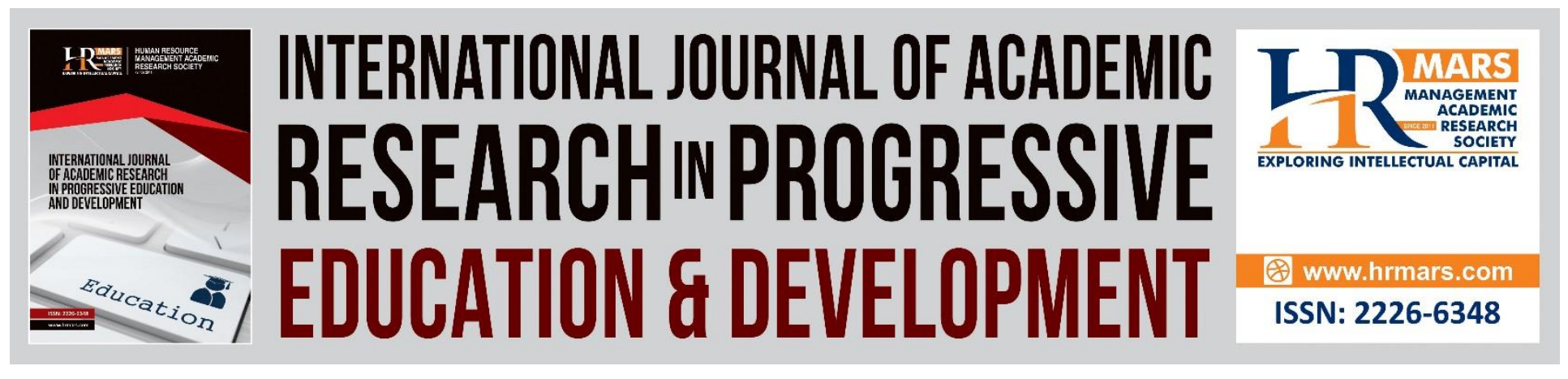

\title{
The Design of GIFTED Motivation Module Using the ADDIE Model Approaches Among the Gifted and Talented Students
}

\author{
Amnah Zanariah Abd Razak, Sahlan Surat, Rosadah Abd Majid
}

To Link this Article: http://dx.doi.org/10.6007/IJARPED/v9-i2/7494

DOI:10.6007/IJARPED/v9-i2/7494

Received: 28 March 2020, Revised: 30 April 2020, Accepted: 10 May 2020

Published Online: 26 June 2020

In-Text Citation: (Razak \& Majid, 2020)

To Cite this Article: Razak, A. Z. A. S. S., \& Majid, R. A. (2020). The Design of GIFTED Motivation Module Using the ADDIE Model Approaches Among the Gifted and Talented Students. International Journal of Academic Research in Progressive Education and Development, 9(2), 509-517.

Copyright: (C) 2020 The Author(s)

Published by Human Resource Management Academic Research Society (www.hrmars.com)

This article is published under the Creative Commons Attribution (CC BY 4.0) license. Anyone may reproduce, distribute, translate and create derivative works of this article (for both commercial and non-commercial purposes), subject to full attribution to the original publication and authors. The full terms of this license may be seen

at: http://creativecommons.org/licences/by/4.0/legalcode

Vol. 9(2) 2020, Pg. 509 - 517

http://hrmars.com/index.php/pages/detail/IJARPED

JOURNAL HOMEPAGE

Full Terms \& Conditions of access and use can be found at http://hrmars.com/index.php/pages/detail/publication-ethics 


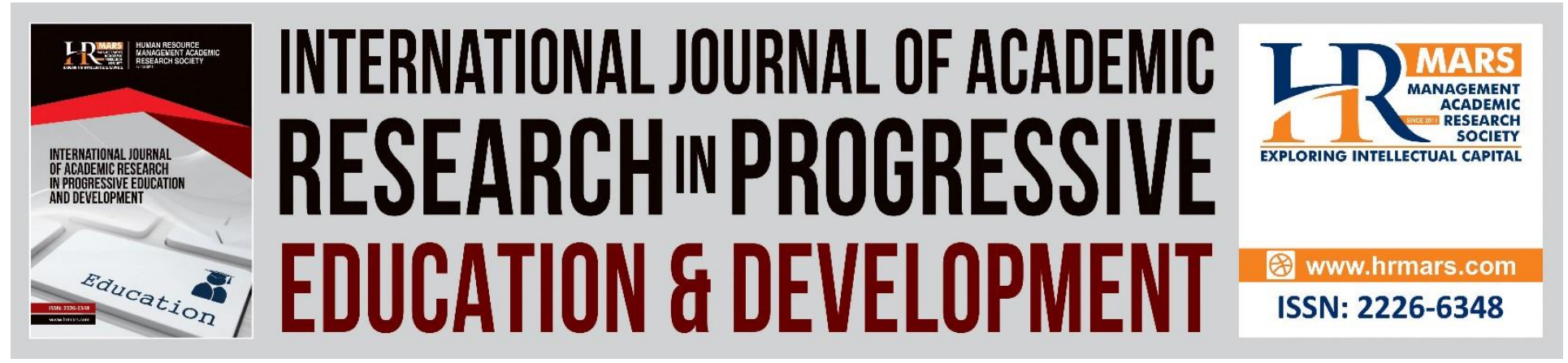

\title{
The Design of GIFTED Motivation Module Using the ADDIE Model Approaches Among the Gifted and Talented Students
}

\author{
Amnah Zanariah Abd Razak, Sahlan Surat, Rosadah Abd Majid \\ Faculty of Education, Universiti Kebangsaan Malaysia (UKM), Malaysia.
}

\begin{abstract}
This study aims explore the process of development of GIFTED motivational module using the Design and Development Research (DDR) approach using the ADDIE Model. The development of the GIFTED motivational module for social issues involves the issues of perfectionism, social anxiety and overexcitabilities. Based on the analysis report on the need for perfectionism issues, social anxiety and overexcitabilities are three most common issues experienced by talented students. It is important to address the socio-emotional gap that occurs among these gifted and talented students by developing an intervention module to address this issue. The design and development of this module used the ADDIE approach because the ADDIE model is a systematic model based on a well-defined implementation strategy that can provide good input to the instruction module. The ADDIE model has also been widely used and is ideal as a basis for the development of the GIFTED module. The ADDIE model consists of five phases namely; a) analysis, b) design, c) development, d) implementation e) evaluation. The results of this five-phase study have established a strong motivational module with expert consent as well as a high validity and reliability. Furthermore, in each phase there is an enhancement process for modifying the module to achieve the planned objectives. The final evaluation results of this module prove that this module can assist the process of socio-emotion competence for gifted and talented students. Keywords: ADDIE Model, Socio-Emotion, Perfectionism, Social Anxiety, Overexcitabilities, Gifted and Talented.
\end{abstract}

\section{Introduction}

Gagné, (2015) thought that students' intelligence is geared towards two types of individual abilities that are natural ability and skills that can be polished in a systematic way, known as the gifted and talent. Both capabilities are described in the Differentiating Model of Giftedness and Talent (DMGT). Gifted and talented students (GTS) are often known as intelligent individuals with skills in problem solving. But the problem-solving skills depend on their natural potential and are supported by a supportive environment. 
Goetz, et al. (2008) argued that these gifted and talented students (GTS) can be regarded as a coin with two faces. The faces are analogous to the cognitive and socio-emotion. According to him, the discussion on the issue of cognitive and socio-emotion of the GTSs cannot be separated as they are interrelated. As such, in addition to being excited by the intellectual power of the students, at the same time we need to examine the socio-emotional issues of the students as either they are adaptive (addressable and positive) or maladaptive (problematic and unsuccessful). In other words, we need to be aware of the strengths and weaknesses of these talented students in order to polish the true potential of these gifted and talented students.

\section{The Purpose of the Study}

The purpose of this study was to introduce the development of the GIFTED motivational module using ADDIE model which is a systematic instructional design that assists the process of module development for the issues of perfectionism, social anxiety and overexcitabilities among gifted and talented students

\section{Instructional Design of the ADDIE Model}

This design is a systematic process in producing educational development and training modules to help students solve problems. Previous studies have shown that many researchers have used the ADDIE model framework as a reference in their developmental study. This ADDIE model is one of the approaches that can guide the development of structured modules (Almomen et al., 2016).

In the field of education, we do need a structured system, the need for training to produce effective teaching and learning sessions. With this instructional design, we can evaluate the outcomes we will be measuring, which are the perceptions, knowledge and skills acquired by our target Azimi \& Rastegarpour (2015). Gifted and talented education needs a measurable assessment process to enhance the socio-emotional adjustment of these students.

The ADDIE model is chosen in this study as it is known as a good model and has been widely used in education. It is also flexible to implement and has a variety of techniques that can be used in the final evaluation process whether formative or summative assessments. ADDIE model according to Aldoobie (2015) is a model that has a systematic process that adopts the ADDIE acronym which means analysis phase, design phase, development phase, implementation phase and evaluation phase.

The ADDIE model is the basis for a five-component instruction design process. ADDIE is an acronym for the components involved in the design process of this instruction that are; $A$ Analysis, D - Design, D - Develop, I -Implement, and E -Evaluate (Gagne et al. 2005). 


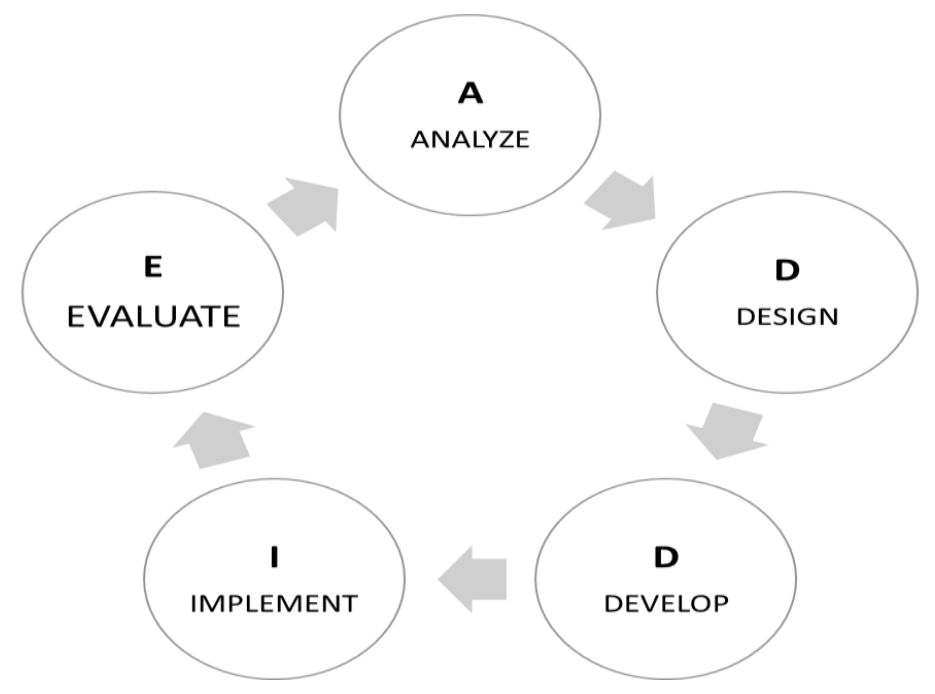

Figure 1.1 ADDIE Model (Gagne et al. 2005)

Instructional design is also known as instructional technology which means a systematic process that assists you in designing and developing an effective design with the help of the environment by using specific strategies to achieve the objectives of an instructional design (Aldoobie, 2015).

The process in this ADDIE model takes place when we identify gaps in the problems we encounter after we go through the process of analysing the needs of the issues being studied. So, we are looking for a solution to the real issue Welty (2007). The next phase of the development of the GIFTED module will be described based on the five phases in the ADDIE model;

\section{Analysis Phase}

The analysis phase is the first phase in the ADDIE model. According to Gagne et al. (2005), this phase is an important phase that identify the real issues that are occurring in the studied population for the development of a module. The analysis phase is carried out to identify the issues and needs of the target as well as to study the requirements of the criteria needed for the development of this module. The requirements of the target and the module are considered in the development phase for the module activities. Moreover, Gagné \& Schader, (2005) stated that the developed instruction should be able to help resolve the issues faced by the gifted and talented students. In the need analysis phase, the researcher conducted a survey study for; a) analysis of module developmental needs, b) module criterion analysis, c) analysis of counselling case documents in 2018 and d) survey of the socio-emotional level of perfectionism, social anxiety and overexcitabilities among the gifted and talented students population in Negeri Sembilan. The findings of the need analysis will be used in the design phase of this module.

\section{Design Phase}

The design phase determines which information that will be passed on to the next phase that is the development phase. In this phase, the objectives for developing the GIFTED module are 
identified. Then, the objectives for the module will be developed. For the GIFTED module, the objective is to understand student perfectionism, to reduce the level of social anxiety among student and to understand the issue of exceptional enthusiasm among GTSs. In the design phase, the integration of theory is formulated. Information from sub-theories will give ideas on how to plan activities based on the selected theories. Subsequently, instructional strategies are developed through the preparation of lesson and learning plans. This lesson plan contains elements across the curriculum (EMK) and the 21st Century Education (PAK21). Through the design phase, the researcher obtained the design specifications to produce an initial draft for the prototype of the GIFTED module.

\section{Development Phase}

The development phase is for teacher to prepare the instructional materials that will be used in the real learning environment. Earlier on, a briefing for teachers will be held to guide teachers in understanding the contents of the GIFTED Module. This will help the teacher to carry out the teaching as required by the researcher based on the instructional plan for each activity provided by the researcher. This development phase is the phase in which the module is implemented. Later in this phase, a pilot study is conducted using the module prototypes in order to improve the quality of this module. Feedback from teachers and students is considered for module improvement. In the implementation phase, the researcher also conducted the validity and usability study of the GIFTED module after conducting the pilot study. Content validity will involve the opinions of 15 experts while the language validity will involve three language experts. The reliability of the module will be derived from the feedback from 30 students who are involved in the pilot study. The validity and reliability questionnaire are administered to obtain the validity and reliability of this module. Good values of validity and reliability allows this module to be continued in the next phase of the real evaluation.

\section{Implement Phase}

The implementation process in this phase involves the process of conducting usability tests or actual evaluation by two teachers on a group of 30 students ( 15 boys and 15 girls). This phase involves the process of implementing the module against the target for eight weeks. Therefore, in this phase the researcher will be conducting the usability test of the module activities on smart and talented students. Once this module is successfully administered to the students with the help of trained teachers, the module will go through the next phase that is evaluation.

\section{Evaluation Phase}

The evaluation of this module is divided into two parts, namely formative and summative evaluation. Formative evaluation is carried out throughout the module in stages for each activity in order to know the students' and teachers' views. While summative evaluation is the overall evaluation of module activities carried out at the end of this study. The form used to evaluate the GIFTED module in term of effectiveness involves the pre and post-tests and the second test is the usability test of the module. Both tests are important to identify whether the module's objectives are achievable and understandable and can be interpreted in behavioural terms. This process of assessment is important for assessing whether the material has reached the required 
level (Holzinger, 2005; Kun, 2014). Module usability studies are an important phase to consider in the process of module development in the evaluation phase. Usability test by Lund, (2001) has been implemented in various fields to test the quality of the product or design that is based on the user's opinion (Eysink, Gersen, \& Gijlers, 2015). According to Rubin \& Chisnell (2008), usability means that a program or product that is produced is not disappointing when used. Usability assessments are made so that there is room for improvement before the end of the study. At the end of this assessment test, interviews will be conducted on a group of four students and two teachers who are working on this GIFTED module. In this evaluation phase, the module's strength and weaknesses can be identified. All this information is analysed for the improvement of the module.

The results of the final evaluation (effectiveness test) showed that this GIFTED module could reduce social anxiety and increase perfectionism and overexcitabilities among students. For usability test, this module had a high level of usability and was suitable for implementation. The findings of the interviews also supported that the activities and approaches were suitable for gifted and talented students. Through this module, students and teachers also understand the issues of perfectionism, social anxiety and overexcitabilities. Therefore, the objective of the GIFTED module usability study was successfully achieved. 
Vol. 9, No. 2, 2020, E-ISSN: 2226-6348 @ 2020 HRMARS

Table 1 shows a summary of the ADDIE Model phases that have been implemented in the development of the GIFTED module.

Table 1 The ADDIE model phases and a summary of the processes that the researcher has implemented for each phase.

\begin{tabular}{|c|c|c|}
\hline \multicolumn{2}{|c|}{ Phases in ADDIE model } & Process results from the ADDIE model \\
\hline 1. & Analysis & $\begin{array}{l}\text { - Need analysis } \\
\text { - Criteria analysis } \\
\text {-Document analysis of counseling cases } \\
\text { throughout } 2018 . \\
\text { - The socio-emotional level of; } \\
\text { Perfectionism } \\
\text { Social anxiety } \\
\text { Overexcitabilities }\end{array}$ \\
\hline 2. & Design & $\begin{array}{l}\text { - Formulate the module's objectives } \\
\text { - Integrating theories } \\
\text {-Develop the lesson plans by } \\
\text { incorporating the } 21^{\text {st }} \text { Century Education } \\
\text { and the elements across the curriculum } \\
\text { into the teaching. } \\
\text { - GIFTED module prototype }\end{array}$ \\
\hline 3. & Development & $\begin{array}{l}\text { - Pilot test } \\
\text { - Content validity } \\
\text { - Language validity } \\
\text { - Reliability }\end{array}$ \\
\hline 4. & Implementation & $\begin{array}{l}\text {-GIFTED module implementation in } \\
\text { actual settings. } \\
\text {-Identify the weaknesses and strengths } \\
\text { of the module through formative testing } \\
\text { after each activity. }\end{array}$ \\
\hline 5. & Evaluation & $\begin{array}{l}\text {-Formative and summative evaluations. } \\
\text {-Evaluation of module effectiveness } \\
\text {-Evaluation of module usability } \\
\text {-Interview with students and teachers } \\
\text { about the GIFTED module. }\end{array}$ \\
\hline
\end{tabular}

This article focused on the ADDIE process involved in the development of this GIFTED module. Findings for each phase will be reported further in future publications. The findings of each phase begin with the needs analysis data and conclude with a test of the effectiveness and usability in the final phase that is the module evaluation phase. Each phase in the development of this module complements each other and supported by findings evidences and the quantitative analysis and reflection sessions with students and teachers. 
Vol. 9, No. 2, 2020, E-ISSN: 2226-6348@ 2020 HRMARS

Module development uses the ADDIE approach which is a useful process in product development of this module. This systematic process complements each other and then undergoes testing and improvement processes for the usability of the module in order to produce a high-quality product.

\section{Conclusion}

The ADDIE model has proven effective in the development of the GIFTED motivation module. Each phase is interrelated and has a comprehensive set of improvement and systematic processes. It has a relevant and clear process to follow, in which the output of one phase is the key information (input) for the next processes.

An overview of the ADDIE model process is expected to assist future researchers in producing effective instruction module innovations. The result of the development of this GIFTED module is to produce students who are socially competent through the activities developed in this module and through five processes in the ADDIE model. The researcher is suggesting that the ADDIE model should use more widely in the field of educational psychology and as a guide in other fields as it is proven to help produced evidence base research in order to produce a highquality product.

\section{Acknowledgement}

The researchers would like to thank the Ministry of Higher Education (KPT) for SLAB scholarships for the PhD studies of the first researchers. We would like to give the highest appreciation to the supervisor who provided guidance in the production of this research paper. We would also like to thank GENIUS Insan College, Universiti Sains Islam Malaysia (USIM) and the Universiti Kebangsaan Malaysia (UKM) for helping to make this study a success.

\section{Corresponding Author}

Amnah Zanariah Abd Razak

Universiti Kebangsaan Malaysia (UKM), Malaysia.

Email: amzar2010@gmail.com

\section{References}

Aldoobi, N. (2015). ADDIE Model. American International Journal Of Contemporary Research, 5(6), 361-373.

Almomen, R. K., Kaufman, D., Alotaibi, H., Al-Rowais, N. A., Albeik, M., \& Albattal, S. M. (2016). Applying the ADDIE-Analysis, Design, Development, Implementation and EvaluationInstructional Design Model to Continuing Professional Development for Primary Care Physicians in Saudi Arabia. International Journal of Clinical Medicine, 07(08), 538-546. https://doi.org/10.4236/ijcm.2016.78059

Azimi, K., Hassan, R., \& Ahmadigol, J. (2015). A Survey of the Effectiveness of Instructional Design ADDIE and Multimedia on Learning Key Skills of Futsal. Journal of Educational and Management Studies, 5(3), 180-186. Retrieved from www.science-line.com

Eysink, T. H. S., Gersen, L., \& Gijlers, H. (2015). Inquiry learning for gifted children. High Ability 
INTERNATIONAL JOURNAL OF ACADEMIC RESEARCH IN PROGRESSIVE EDUCATION AND

DEVELOPMENT

Vol. 9, No. 2, 2020, E-ISSN: 2226-6348 @ 2020 HRMARS

Studies, 26(1), 63-74. https://doi.org/10.1080/13598139.2015.1038379

Gagné, F. (2015). Academic talent development programs: a best practices model. Asia Pacific Education Review, 16(2), 281-295. https://doi.org/10.1007/s12564-015-9366-9

Gagné, F., \& Schader, R. M. (2005). Chance and talent development. Roeper Review, 28(2), 8890. https://doi.org/10.1080/02783190609554343

Goetz, T., Preckel, F., Zeidner, M., \& Schleyer, E. (2008). Big fish in big ponds: A multilevel analysis of test anxiety and achievement in special gifted classes. Anxiety, Stress and Coping. https://doi.org/10.1080/10615800701628827

Holzinger, A. (2005). Usability Engineering Methods for Software Developers. Communications of the ACM, 48(1), 71-74.

Kun, C. T. (2014). Penambahbaikan sistem pengurusan KOKUM sekolah (SPKS) berdasarkan kebolehgunaan terpilih. Universiti Kebangsaan Malaysia (UKM).

Lund, A. M. (2001). Measuring usability with the USE questionnaire. 8(2), 3-6.

Rubin, J., \& Chisnell, D. (2008). Handbook of Usability Testing: How to Plan, Design and Conduct Effective Tests. In Wiley Publishing, Inc (Second Edi). Indiana: Wiley Publishing, Inc.

Welty, G. (2007). The 'Design' Phase of the ADDIE Model. Journal of GXP Compliance, 11(4), 4048. Retrieved from http://www.wright.edu/ gordon.welty/J_GXP_C_Design_07_07.pdf 